\author{
Nepal Journal of Multidisciplinary Research (NJMR) \\ Vol. 3, No. 2, September 2020. Pages. 97-108 \\ ISSN: 2645-8470 (Print), ISSN: 2705-4691 (Online) \\ DOI: https://doi.org/10.3126/njmr.v3i2.33040
}

\title{
The Impact of Social Media on Navodit College Students
}

\author{
Anup Adhikari \\ BABSW $3^{\text {rd }}$ Year, Navodit College \\ Samakhushi, Kathmandu Nepal \\ adhikarianup60@gmail.com
}

Received: August 26, 2020; Revised \& Accepted: October 4, 2020; Published: October 18, 2020

(C) Copyright: Adhikari (2020).

(c) (1) This work is licensed under a Creative Commons Attribution-Non Commercial 4.0 International License.

\begin{abstract}
Today social media has been commonly used by everyone especially the young people and the institutions too are getting into this modern medium of communication rapidly. It has created a new world of collaborations and communication. And it has also facilitated an easy and economical way of communication between friends and families across the world. On the other side, social media has dragged the youngsters and students into it and to the extent that it fritters away their valuable time, energy and money. Many students spent most of the time in those sites which ultimately does not contribute to their lives as well as in their academic life. Now-a-days, many social media have been invented from local and multinational company in national and international level. The purpose of this research paper is to assess the impact of social media on Navodit College students. The researcher tries to examine and identify the impact of social media in the research. The objective of this study was to explore and investigate the factors compelling the college students to using social media. Qualitative and Quantitative, both research methods were used while conducting the research and this research is done in Navodit College (Tribhuvan University, Nepal). 109 Bachelors level students was involved to fill up the questionnaire of the academic year of 2019/2020. Research upon social media is more important because it has both positive and negative impact upon the students in their psychological and physical aspect.
\end{abstract}

Keywords: college students, impact, social media 


\section{Nepal Journal of Multidisciplinary Research (NJMR) \\ Vol. 3, No. 2, September 2020. Pages. 97-108 \\ ISSN: 2645-8470 (Print), ISSN: 2705-4691 (Online) \\ DOI: https://doi.org/10.3126/njmr.v3i2.33040}

\section{Introduction}

Social media is an instrument used for communication. Media defines Television, Radio, Newspaper, Online, Internet etc. Similarly, social media also denotes them as well as it focuses on the new emerging sites which helps to disseminate the news and information to the mass audiences. Google, Facebook, Twitter, Youtube, Instagram, Online News Portal, Word press etc. are some example of social media. The research topic is related to The Impact of Social Media on Navodit College Students. Social Media has been defined as websites which allow profile creation and visibility of relationships between users (Boyd \& Ellison, 2008). A taxonomy of "social media" splitting the field into 6 distinctive categories (Blogs, Social Networking Sites, Collaboration Projects, Content Communities, Virtual Social Worlds, and Virtual Game Worlds) introduced by Kaplan \& Haenlein (2010).

Camila, İbrahim and Dalhatu (2013) indicated that social media has become one of the most influential communication tool which could be effectively used on teaching process.

\section{Statement of the Problem}

Social Media impacts a lot to the people. It is known as the modern technology but it has its own uniqueness in nature. Mainly youths are more focused towards these kinds of social media. Kalra \& Manani (2013) argue that excessive use of these sites not only have long lasting effect on psyche of students but also affects the physical, mental and social aspect of life. Nalwa \& Anand (2004) advised and recommended that those who are addicted users love to use the internet to set back their personal and professional responsibilities in which the final outcome is poor academic performance.

\section{Objective of the Study}

General Objective

$>$ To investigate and explore the impact of social media among Navodit College students.

1.2 Specific Objectives

> To examine the impact of social media on academic performance among the students.

$>$ To identify the benefits obtained from using the social media.

$>$ To ascertain what students use social media sites for.

$>$ To establish whether online social networking sites are used by students to improve their academic performance.

$>$ To establish what other purpose, apart from communication, students use social networking sites for.

\section{Limitation of the Study}

The research has some limitations such as limited time, budget consumption and certain geographical area.

\section{Justification of the Research}

Today's generation is the generation of technology and new innovation. Thus, to examine and identify the impact of social media on Navodit College students the research had done. 


\section{Nepal Journal of Multidisciplinary Research (NJMR) \\ Vol. 3, No. 2, September 2020. Pages. 97-108 \\ ISSN: 2645-8470 (Print), ISSN: 2705-4691 (Online) \\ DOI: https://doi.org/10.3126/njmr.v3i2.33040}

The topic was most relevant to conduct research because it provides the overall positive and negative impacts of social media which ultimately provides the developing status of psychology and education of Bachelors Level students of Navodit College. Tezer (2017) belies that sharing course related videos and photos, intensively engaging with course-related discussions and exchanging ideas would positively affect the academic achievements of the students thus, it would be beneficial to use social media tools for educational purposes. Such types of research need to perform from other Colleges to find the both negative and positive impacts.

\section{Literature Review}

Social media are a collection of internet websites, services, and practices that support collaboration, community building, participation, and sharing (Junco, Heibergert, \& Loken, 2010). Advantages of social media apparently include fast and effective communication among people, dynamic social and collaborative environment and convenient access to information as well as promoting tool for businesses (Eduardo Guedes, 2016). The relationship between Facebook and well-being appears to become positive over the college years, possibly because upper class students use Facebook to connect socially with their peers and participate in college life (Lusk, 2010). The academic success of students can improve by social media if they are used correctly in the classroom environment. It also encourages active participation in the class (Yazan M. Alghazo, 2017).

A study conducted by Karpinski \& Duberstein (2009), of Ohio Dominican University on college students who use social network have significantly lower grade point averages (GPAs) than those who do not. They also mentioned that among various unique distractions of every single generation, Facebook remains a major distraction of current generation (Owusu-Acheaw \& Larson, 2015).

Miguel (2009), focused on the relationship between time spent on Facebook and the academic performance of students. The overall findings indicated "more time on Facebook equals slightly lower grades". In his study, the average Facebook user had a GPA of 3.0 to 3.5, while the non-Facebook user had a GPA of 3.5 to 4.0. Also, the average Facebook user study for 1 to 5 hours per week, while the non -Facebook user would study 11 to 15 hours per week. Although, providing a detailed perspective on social media use among university students and underscoring that such use can produce both positive and negative consequences, according to the India Today-Nielsen Media Research study, in June 2016, almost 25 percent of students' time on the internet is now spent on social networking websites (Reynol Junco, 2010).

\section{Methodology}

The data was collected using primary data set through the distribution of questionnaire. Methodology is the set of methods and principles that you use when studying a particular subject or doing a particular kind of work (Longman Dictionary, 2020). Both, Qualitative and 


\section{Nepal Journal of Multidisciplinary Research (NJMR) \\ Vol. 3, No. 2, September 2020. Pages. 97-108 \\ ISSN: 2645-8470 (Print), ISSN: 2705-4691 (Online) \\ DOI: https://doi.org/10.3126/njmr.v3i2.33040}

Quantitative method is chosen for the research. The method was used to collect data and information from all of students of Navodit College (Tribhuvan University, Nepal) during lecture hours of the Bachelors Program of 2019/2020 academic year. According to Baker (2000) questionnaires to acquire primary data the best suitable research are based on experiment, observation and survey.

After the collection of data, the results were analyzed with the use of the IBM Statistical Package for Social Science (SPSS) and the result shown in tables with corresponding frequencies and percentage. After the distribution of the questionnaire, one hundred and nine copies were retrieved. This gave a response rate of $95.5 \%$, which was representative of the whole questioner. The impressive response rate was obtained because the data was collected during lecture hours in the various departments. Respondents were given 1 hour to complete the questionnaires.

\section{Presentation and Data Analysis}

The data of the research topic 'The Impact of Social Media on Navodit College Students' was analyzed by Statistical Package for Social Science (SPSS) software. There are total 109 numbers of students who was involved in this research directly and there are 19 questions in total. Analyzation of the outcome of the data is presented below:

Table 1 : Table of mean of hours and advantages of using social networks.

\begin{tabular}{|c|c|c|}
\hline & $\begin{array}{l}\text { How many hours do you spend on } \\
\text { social networks daily? }\end{array}$ \\
\hline & & Mean \\
\hline \multirow{5}{*}{$\begin{array}{l}\text { What is/are the best } \\
\text { advantage(s) of } \\
\text { using } \\
\text { networks? }\end{array}$} & $\begin{array}{l}\text { Sharing } \\
\text { information/work } \\
\text { quickly }\end{array}$ & 2.81 \\
\hline & $\begin{array}{l}\text { Meeting new people can } \\
\text { help you socialize }\end{array}$ & 2.63 \\
\hline & $\begin{array}{l}\text { Learning technology } \\
\text { becomes easier }\end{array}$ & 4.41 \\
\hline & $\begin{array}{l}\text { Keeping in touch with } \\
\text { friends is convenient }\end{array}$ & 4.00 \\
\hline & None & \\
\hline
\end{tabular}

Above mentioned table presents the mean of hours and advantages of using social networks on Navodit College students. Here in table 1, we can found that the students spends around 2.81 hours by sharing information/work quickly. Similarly, 2.63 hours were spent for meeting new people and can help the students to socialize. Then, we found that average of 4.41 hours was spent by the students to make their learning technology becomes easier and about 4.0 hours of 


\section{Nepal Journal of Multidisciplinary Research (NJMR) \\ Vol. 3, No. 2, September 2020. Pages. 97-108 \\ ISSN: 2645-8470 (Print), ISSN: 2705-4691 (Online) \\ DOI: https://doi.org/10.3126/njmr.v3i2.33040}

the time was used to keeping in touch with friends is convenient. So, the table shows that the students spends more hours of time by realizing the learning technology becomes easier for them and the less hours of time that is, 2.63 hours is spent for meeting new people which can make them socialize.

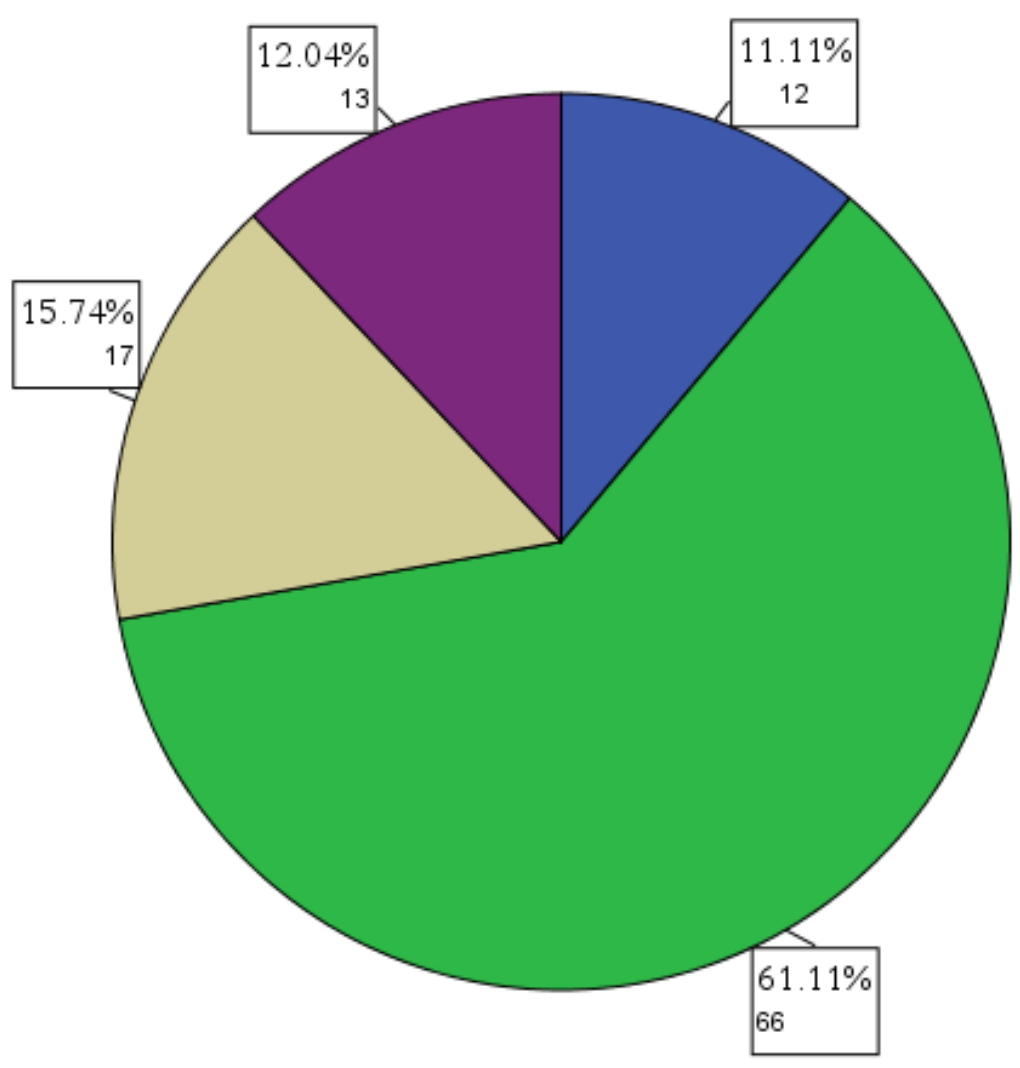

Why do you use social
networks?

Socialize and make new friends

Remind updated about what is trending Collaborate with $\square$ fellow students and study

As a source of recreation and relaxation

Fig 1: Pie chart on why do you use social networks?

The above mentioned pie chart shows the answer of the question to why you use social networks for the students. Among the total students 11.11 percentage use social networks for socialize and make new friends. Similarly, to remain updated about what is trending, 61.11 percentage use social networks. Likewise, to collaborate with fellow students and study 15.74 percentage students use social networks and about 12.04 percentage students use the social networks as a source of recreation and relaxation. 


\section{Nepal Journal of Multidisciplinary Research (NJMR)}

Vol. 3, No. 2, September 2020. Pages. 97-108

ISSN: 2645-8470 (Print), ISSN: 2705-4691 (Online)

DOI: https://doi.org/10.3126/njmr.v3i2.33040

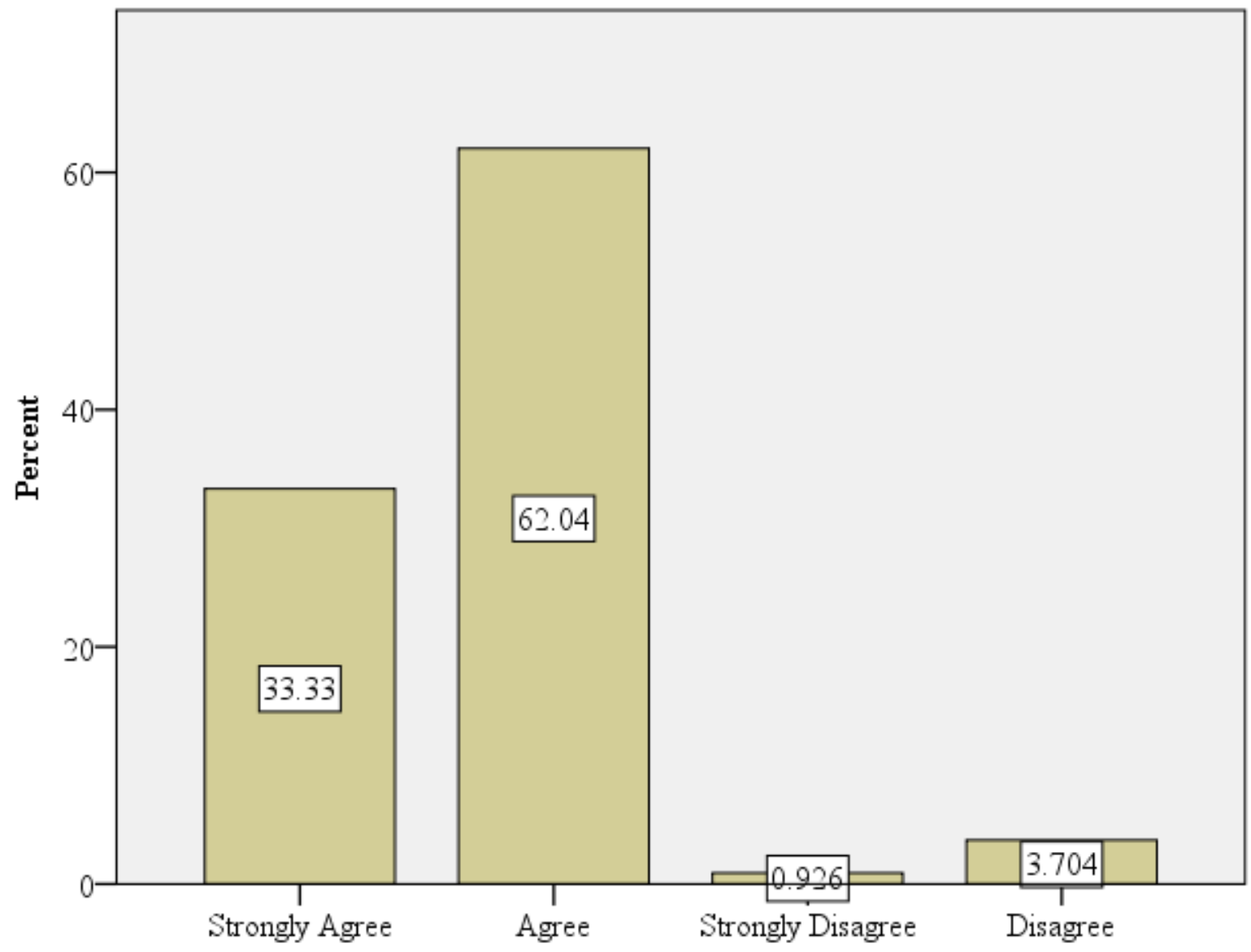

Do you think using some kind of social networking is essential for today's life?

Fig 2: Bar diagram on do you think using some kind of social networking is essential for today's life?

The mentioned bar diagram shows the thinking perspectives of using some kind of social networking is essential for today's life for the students. Among them, 33.3 percentage strongly agree, 62.04 percentage agree, 0.926 strongly disagree and 3.704 percentage disagree to the statement. So, almost high percent and the number of the students agrees that the using some kind of social networking is essential for today's life and it has great importance in today's world. 


\section{Nepal Journal of Multidisciplinary Research (NJMR)}

Vol. 3, No. 2, September 2020. Pages. 97-108

ISSN: 2645-8470 (Print), ISSN: 2705-4691 (Online)

DOI: https://doi.org/10.3126/njmr.v3i2.33040

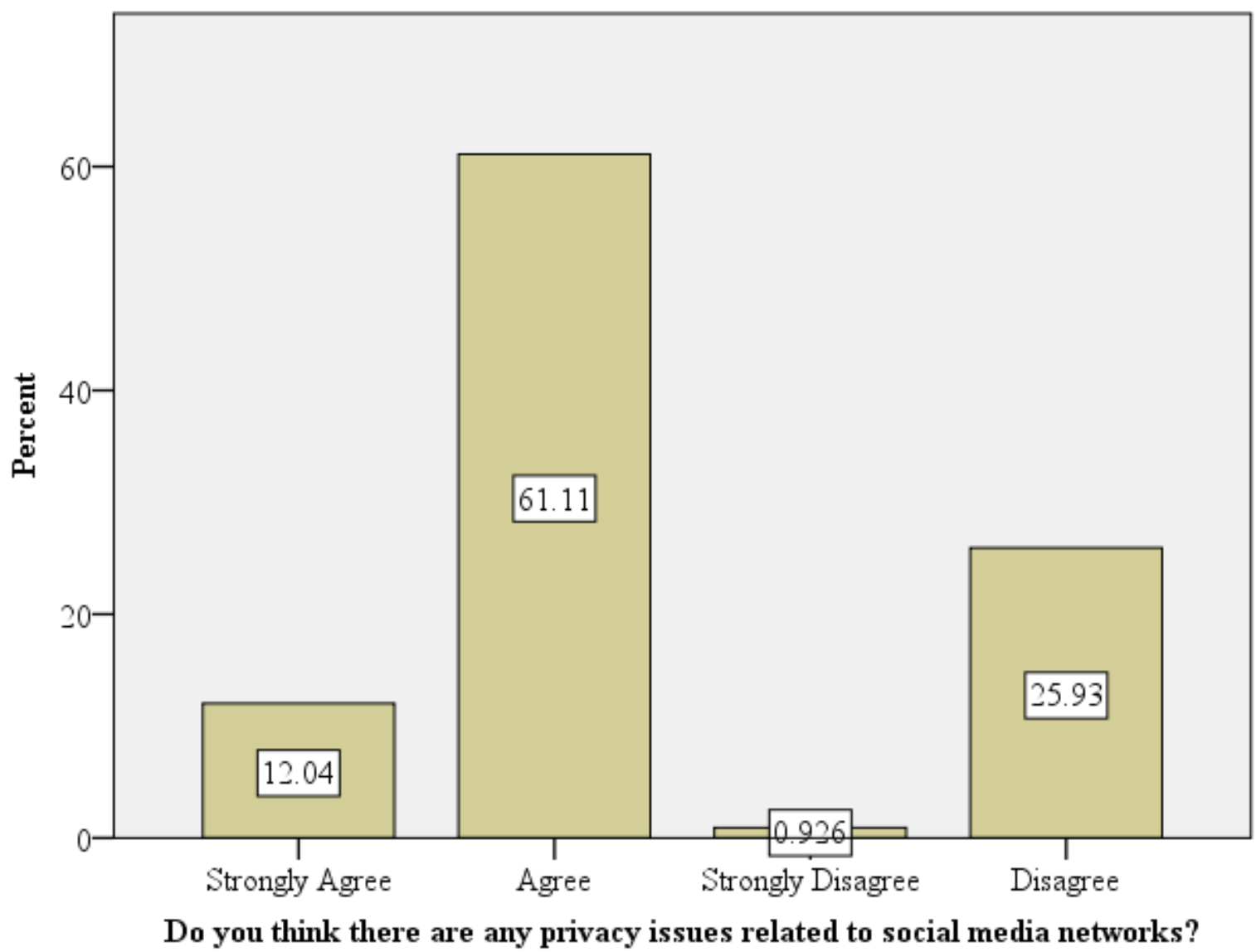

Fig 3: Bar diagram on do you think there are any privacy issues related to social media networks?

This is the Bar diagram on do you think there are any privacy issues related to social media networks and was was conducted on Navodit College students. 12.04 percentage strongly agree, 61.11 percentage agree, 0.926 percent strongly disagree and 25.93 percentage disagree on the privacy issues related to social media networks. Thus, high number of students agrees that there is always the question on privacy issues of an individual while using social media networks. 


\section{Nepal Journal of Multidisciplinary Research (NJMR)}

Vol. 3, No. 2, September 2020. Pages. 97-108

ISSN: 2645-8470 (Print), ISSN: 2705-4691 (Online)

DOI: https://doi.org/10.3126/njmr.v3i2.33040

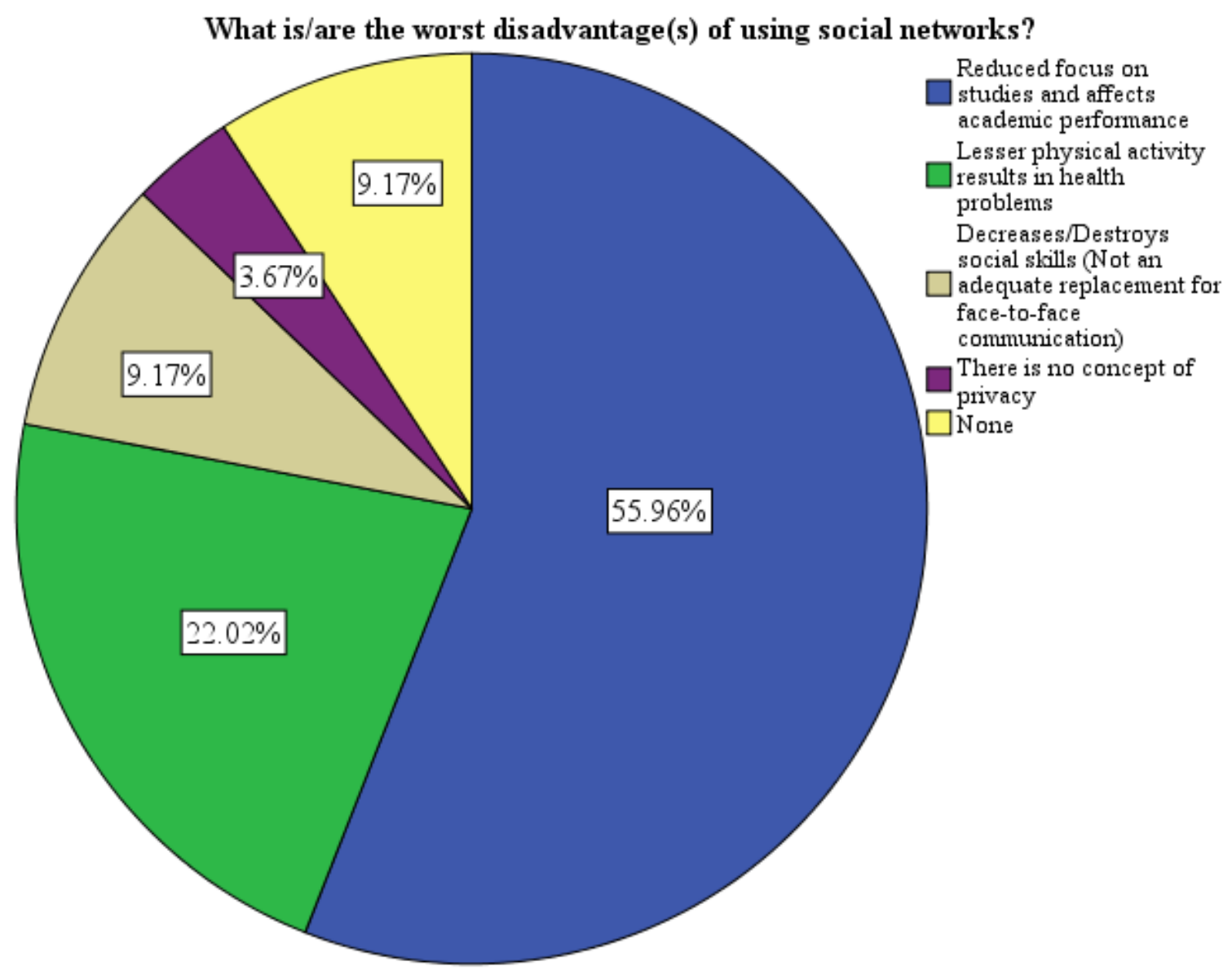

Fig 4: Pie chart on what is/are the worst disadvantages of using social networks?

The above mentioned pie chart presents what is/are the worst disadvantages of using social networks on college students. The data shows that 55.96 percentage of students tells that using of social networks can reduce focus on studies and affects academic performances. Similarly, 22.02 percentage students tells using of social networks that it makes lesser physical activity results in health problems. Likewise, 9.17 percentage students believes that it decreases/destroys social skills (not an adequate replacement for face to face communication). Similarly, 3.67 percentage students tells that there is no concept of privacy of using social networks. Thus, more number of students believes that the using of social networks can reduce focus on studies and affects academic performances. 
Nepal Journal of Multidisciplinary Research (NJMR)

Vol. 3, No. 2, September 2020. Pages. 97-108

ISSN: 2645-8470 (Print), ISSN: 2705-4691 (Online)

DOI: https://doi.org/10.3126/njmr.v3i2.33040

\begin{tabular}{|l|l|l|l|l|l|}
\hline \multicolumn{2}{|l|}{ Table 2:Is your parent aware of your social networking activities? } \\
\hline \multicolumn{1}{|l|}{} & Frequency & Percent & Valid Percent & $\begin{array}{l}\text { Cumulative } \\
\text { Percent }\end{array}$ \\
\hline \multirow{4}{*}{ Valid } & Yes, all of them & 66 & 60.6 & 60.6 & 60.6 \\
\cline { 2 - 7 } & No, none of them & 7 & 6.4 & 6.4 & 67.0 \\
\cline { 2 - 7 } & Some of them & 36 & 33.0 & 33.0 & 100.0 \\
\cline { 2 - 7 } & Total & 109 & 100.0 & 100.0 & \\
\hline
\end{tabular}

The above mentioned table presents the data of parents' awareness towards social networking activities of the students. According to the table, 60.6 percentage or 66 students' parents were aware of social networking activities of their children. Similarly, 6.4 percentage or 7 students' parents aren't aware of their children activity on social networking and remain, 33.0 percentage or 36 students' parents are aware of some of social networking which was used by their children. The data shows that most of the parents are aware of their children's social networking activities. 


\section{Nepal Journal of Multidisciplinary Research (NJMR)}

Vol. 3, No. 2, September 2020. Pages. 97-108

ISSN: 2645-8470 (Print), ISSN: 2705-4691 (Online)

DOI: https://doi.org/10.3126/njmr.v3i2.33040

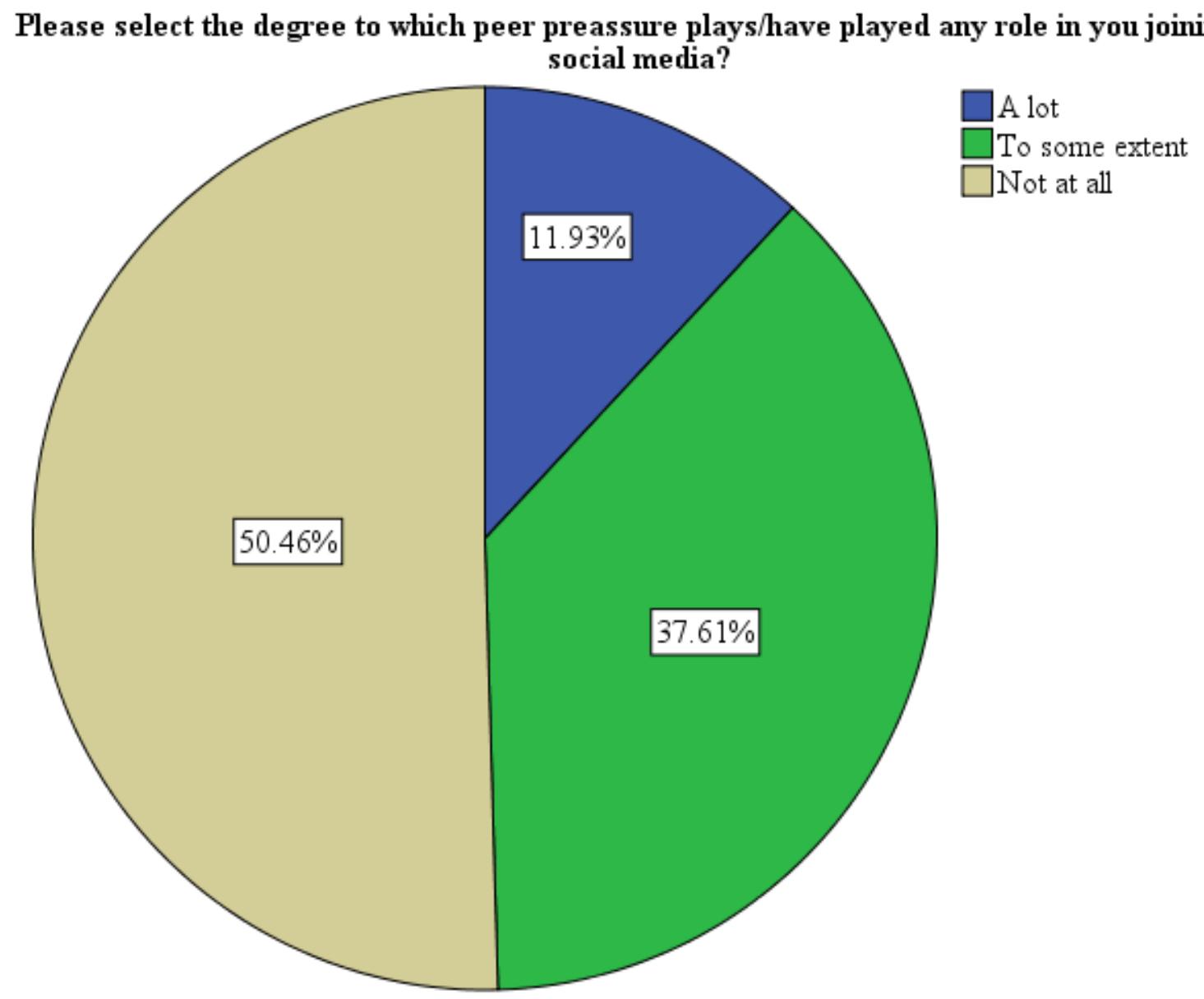

Fig 5: Pie chart on please select the degree to which peer pressure plays have played any role in you joining a social media?

The above mentioned pie chart shows that how the young people connects themselves by the peer pressure to join the social media. According to the chart, 11.93 percentage students have affected a lot to join social media by the peer pressure. Likewise, 37.61 percentage student believes that peer pressure have played the role for them to join social media to some extent. Similarly, 50.46 percentage students have joined social media by themselves by not of their peer pressure. Thus, we can find that almost 50 percentage of students haven't got any peer pressure to join the social media.

\section{Conclusion}

The researcher' have found the impact of social media on Navodit College students at the time of preparing the research report. The respondents reported different impact of social media. Among them, the major impact of social media for the use of social networks is to remain updated about what is trending and to make learning technology easier. Similarly, the research presents disadvantages, privacy issues, parental control and awareness on networking activities and the peer pressure for joining the social media for students. Thus, respondents have their own perception regarding the impact of social media upon them. 


\section{Nepal Journal of Multidisciplinary Research (NJMR) \\ Vol. 3, No. 2, September 2020. Pages. 97-108 \\ ISSN: 2645-8470 (Print), ISSN: 2705-4691 (Online) \\ DOI: https://doi.org/10.3126/njmr.v3i2.33040}

\section{References}

Baker, M. (2000). Selecting a Research Methodylogy. The Marketing Review, 373-397.

Boyd, D. M., \& Ellison, N. B. (2008). Social Network Sites: Definition, History, and Scholarship. Journal of Computer-Mediated Communication, 13, 210-230.

Eduardo Guedes, A. E. (2016, February). Social networking, a new online addiction: a review of Facebook and other addiction disorders. Medical Express. doi:10.5935/MedicalExpress.2016.01.01

Junco, R., Heibergert, G., \& Loken, E. (2010). The effect of Twitter on college student. Journal of Computer Assisted Learning, 1-14. doi: 10.1111/j.1365-2729.2010.00387.x

Kalra, R. K., \& Manani, P. (2013, August). Effect of Social Networking Sites on Academic Achievement Among Introvers and Extroverts. Asian Journal of Social Sciences and Humanities. $\quad$ Retrieved from https://pdfs.semanticscholar.org/beb5/75334acb5d4e21bf987fc889da36eaeae6d0.pdf

Kaplan, A. M., \& Haenlein, M. (2010). Users of the world, unite! The challenges andopportunities of Social Media. Business Horizons.

Karpinski, A. C., \& Duberstein, A. (2009). A Description of Facebook Use and Academic Performance among Undergraduate and Graduate Students. American National Research Association, 1-19.

Longman Dictionary. (2020, August 11). Retrieved from https://www.ldoceonline.com/dictionary/methodology

Lusk, B. (2010, December). Digital natives and social media behaviors: An overview. The Prevention Researcher, 17.

Miguel, R. S. (2009, April 14). Study on Facebook and Grades Becomes Learning Experience for Researcher. Retrieved from TechNewsWorld: https://www.technewsworld.com/story/66805.html

Murat Tezer, A. T. (2017). THE IMPACT OF USING SOCIAL MEDIA ON ACADEMIC ACHIEVEMENT AND ATTITUDES OF PROSPECTIVE TEACHERS. International Journal of Cognitive Research in Science, Engineering and Education, 5. doi:10.5937/IJCRSEE1702075T

Nalwa, K., \& Anand, A. P. (2004, July 5). Internet Addiction in Students: A Cause of Concern. Cyber Psychology \& Behavior, 653-656.

Onyeka Ndidi Camilia, S. D. (2013, July 20). The Effect of Social Networking Sites Usage on the Studies of Nigerian Students. The International Journal Of Engineering And Science, 2, 39-46. Retrieved from http://theijes.com/papers/v2i7/Part.3/F0273039046.pdf

Owusu-Acheaw, M., \& Larson, A. G. (2015). Use of Social Media and Its Impact on Academic Performance of Tertiary Institution Students: A Study of Students of Koforidua Polytechnic, Ghana. Journal of Education and Practice, 94-101. Retrieved from https://files.eric.ed.gov/fulltext/EJ1083595.pdf

Reynol Junco, D. W. (2010, December). The Effect of Gender, Ethnicity, and Income on College Students' Use of Communication Technologies. Cyberpsychology, Behavior, and Social Networking, 13(6), 619-27. doi:10.1089/cyber.2009.0357 


\section{Nepal Journal of Multidisciplinary Research (NJMR)}

Vol. 3, No. 2, September 2020. Pages. 97-108

ISSN: 2645-8470 (Print), ISSN: 2705-4691 (Online)

DOI: https://doi.org/10.3126/njmr.v3i2.33040

Yazan M. Alghazo, J. A. (2017). The Effect of Social Media Usage on Course Achievement and Behavior. Journal of Education and Practice, 8. Retrieved from https://files.eric.ed.gov/fulltext/EJ1131722.pdf 